Sign Systems Studies 49(3/4), 2021, 590-607

\title{
Urban-human faces and the semiotic right to the city: From the USSR propaganda machinery to the participatory city
}

\author{
Elsa Soro ${ }^{1}$
}

\begin{abstract}
Now that the usage and meaning of urban spaces have been dramatically challenged by the global pandemic, several debates and reflections are going on around the manner in which cities - both as concerns the public and the private spaces - have been designed. The article observes how "urban-human face" representations have served different models of urbanity across times and cultures.

Using a framework deriving from semiotics of culture, according to which the city represents a model of the world, the article attempts to interpret how portraits of faces have been modelling the city through different urban faciality mechanisms. The focus is on a sample of what we call 'urban-human faces', ranging from Soviet propaganda posters to the digital \#selfiecity project. The expression refers to series of representations that bring together the city and the face. It can be argued that both the city and the face, produced at a specific historical and cultural moment, with their figurative and plastic elements, deploy the struggle for the city ownership and authorship.

Nonetheless, the commensurability of the city and the face can be just based on the fact that both semiotic configurations represent an excess with the help of cartographic reproduction (the city) and the portrait (the face), respectively. A city can be represented by a face to the extent to which it is also multifaceted as a polylogue. On the basis of such instable commensurability, the article will ultimately attempt to bring together the semiotics of the face and the semiotics of the city.
\end{abstract}

Keywords: faciality; urban semiotics; mediascape; selfies; selfiecities

\section{Introduction: Cities and faces under (re)construction}

Since the beginning of the global pandemic, the images of the cities circulating in the media all over the world have been displaying dystopic scenarios made of vivid contrasts between empty spaces, for instance the traditional tourist and leisure

1 Department of Philosophy and Education Science, University of Turin, Via Verdi 8 - 10124 Torino, Italy/UOC (Open University of Catalonia), Spain; e-mail: elsa.soro@unito.it. 
spaces deserted by visitors, and massive agglomerations of human and non-human actors, namely the queues at the supermarkets or the gathering of patients in the crowded hospital wards, together with the correspondent artefacts.

During the lockdown imposed by the different governments all over the world, the public and commercial spaces, deprived of their dwellers and consumers, have been invoked in public debate and media descriptions as "ghostly", or "surreal", and, thus, such processes have emphasized the intrinsic social character of the urban texture.

While the elements of the city directly related with the urban lifestyle (i.e. interaction, mobility, crowd activities, etc.) have been banned, a parallel process of covering and concealment involves the human face these days: the sanitary masks, recommended or imposed by the authorities cover the mouth and the nose, while the face shields cover the face from the top of the head to below the chin.

On the basis of this, it can be argued that the current debate about the design and planning of cities in an hypothetical postpandemic scenario could be intermingled with a debate on the new aesthetic of the face: the visibility regimes of both the city and the human face have been brought to question: What must remain visible in a face in order to recognize a person? Which parts of the city and which aspects of urban life could still remain when the risk of an infectious disease threatens social life?

However, the overlapping between the discourses on the city and those on the human face is not a novelty. The expression 'the face of the city', used both in academic and public debates, refers to the appearance of the city and evokes the fact that for a city, as a face, to be memorable it must leave a certain impression on the visitors.

Sayings such as "the cities change their faces through times" or "cities with a human face" attribute to the city the features of a visage, something that changes over times, but, at the same time, refers to an identity that lasts and can be recognized despite those changes.

There are studies that have already been delving into the ontological affinity between the city and the face by analysing the extent to which a comparison and an analogy can be found between the two notions (Deleuze, Guattari 1980; Black 2011; Mubi Brighenti 2019). Taking into account the existing research, this piece aims at contributing to the debate on the relationship between the city and the face from a different angle. Using a framework deriving from semiotics of culture, according to which the city represents a model of the world, the study attempts to interpret how the representations of human face and the conditions of their production reveal different cities' ideologies across times and cultures.

It is worth noting that the human face is a recurrent iconographic figure in urban landscape: for instance, in the global metropolis street artists use the urban 
walls as an informal and ephemeral canvas for portraits of the human face ${ }^{2}$, while digital billboards in the city centres have been advertising products through the model human faces to catch the consumers' attention.

With this in mind, the piece will focus on a sample of "human-urban face" portraits, that is, a series of representations that bring together the city and the face in a meaningful composition. Arguably, each of them, produced in a specific historical moment, deploys the struggle for the city ownership and authorship with its figurative and plastic elements.

The study proceeds from the assumption that the city is a contested object, whose significance is produced by different forces and tensions that struggle for the city ownership as shown by a vast literature ${ }^{3}$ in urban studies, geography and urban sociology that has been focusing on political struggles (Davis 1990; Hardt, Negri 2009), economic asymmetries and social justice (Harvey 1973; Schneider, Susser 2003), privatization of urban space (Atkinson, Blandy 2006), residential and spatial segregation (Massey 1996; Atkinson et al. 2004), social inequality (Skop 2006) and creation of plural social movements (Castells 1983; Young 1990).

From a semiotic point of view, the work tries to embrace the urban conflict as an overlapping between different writings and rewritings of the urban text undertaken by different potential "authors" who aim to be the custodians of the urban narratives and the urban gaze. Covering a trajectory of a series of "urbanhuman faces", the text will aim to contribute to bringing together the semiotics of the face with the semiotics of the city.

The first part of the article will frame the topic within a literary review of the city as a semiotic object in a permanent tension between plurality and unity.

The trajectory covering "urban-human faces" starts with the representation of the oversized face of the leader who overlooks the crowd in Soviet propaganda. In opposition to socialist ideology, the representations of the capitalist global city deploy the fragmentation of the power scattered on screen refractions. The face of the "leader" pops up on television screens in the private space of the citizens' houses. Later on, with the advent and diffusion of the personal computer and other technological devices, the "real" city is recreated in online virtual worlds and "played" by face avatars. The trajectory is "finalized" by illustrating the "urban-human face" in the participatory rhetoric that reclaims a city co-owned by citizenship.

2 The best-known street artist who put the human face at the centre of his artistic production is JR. The human face is also a recurrent topic in protest street art, a recent example being the series dedicated to George Floyd, the black man killed by a police officer in the city of Minneapolis, Minnesota, U.S.A. in 2020.

3 The list of references gathers those most quoted in the field. Nonetheless it cannot be considered as exhaustive. 
The series does not aspire to be exhaustive - rather, it aims at tracking figurative and plastic patterns of the city iconographies through the face, by bringing together these two unstable semiotic objects.

\section{The semiotic city}

\subsection{The citysphere}

The Tartu-Moscow School of Semiotics has extensively interrogated the structure of the city, understood as a semiotically charged space. Initially, ${ }^{4}$ the spatial concepts were only used metaphorically as an empirical description of culture. Accordingly, the city and its organization was firstly considered by Ivanov (1986: 9) "as a model of universal space".

Since the coining of the concept of the 'semiosphere' (Lotman 1984) ${ }^{5}$, as an analogy to and extension of Vernadsky's (1926) concept of the biosphere, Lotman further interpreted the city as a territorial space for semiosis. In particular, in Universe of the Mind, Lotman (1990: 191) clarified how “[i]n the system of a culture's symbols, the city has an important place. City symbolism can be divided into two main areas: the city as symbolic space and the city as symbolic name". The former area refers to the relationship between the city and "the earth which surrounds it" (Lotman 1990: 191). According to Lotman, a city can be either "isomorphous with the state, and indeed personify it" (for instance Rome as the city and the world), or "be an antithesis to the surrounding world" (Lotman 1990: 191).

Either way the city, according to the vision of the semiotics of culture, is animated by elements of tension and struggle. In his description of St.Petersburg, Lotman (1990: 193) underlined the dimension of "eternal struggle between elements and culture", epitomized by the antithesis between water and stone, present in the myth of the Russian city.

Such tension can be considered as isomorphic to that of the semiosphere one and the latter's polylogue form in which different discourses, semiotic conflicts and relations are woven together, escaping a unique or even a bijective logic of meaning

According to Lotman, the semiosphere is separated from the otherness by its boundaries, the internal topographical organization being characterized by a tension between continuity (with respect to the outside) and discontinuity. Such

4 See the Theses of the Tartu-Moscow School (Uspenskij et al. 2003)

5 Juri Lotman's “On the semiosphere" was first published in 1984 and was an attempt to describe the structural features of the semiosphere in broad terms. However, the concept of the semiosphere was first formulated by Juri Lotman in 1982 inspired by the works of the Russian geologist Vladimir Vernadsky on the noosphere and the biosphere of Earth. 
internal discontinuity of the semiosphere is due, in the first place, to the presence of certain saliences. Lotman and Uspensky (1977[1973]: 237) exemplify this with the example of proper names in mythology, where "space is not conceived as a sign continuum, but as a totality of separate objects bearing proper names. It is as if space were interrupted by intervals between objects and thus absences". Such internal tensions can also be interpreted, at a semiosic level, as the combination between explosive and gradual processes. Such processes are not just understood as the alternation of asynchronous phases that mutually replace each other. Instead, such a tension can give account of a simultaneous process.

The internal topography of the city can be described as highly discontinuous in different respects, both synchronically and diachronically speaking, both temporally and spatially speaking, considering both natural (for instance natural catastrophes) and anthropogenic phenomena (for instance, military sieges, gentrification processes), redesigning and reorganizing the internal urban forces at the level of semiosis.

\section{2 .The semiotic right to the city}

The discontinuity in the city topography can also be attributed to the multiple transformations of the collective action in the permanent struggle for achieving a hegemonic position in the city governance.

In the frontispiece of Thomas Hobbes' Leviathan by Abraham Bosse (1651), the body of the Sovereign King is constituted by the blurring together of individual faces of the citizenry, who face the Sovereign to represent his dominant position over the city.

In contrast, the slogan "right to the city", proposed in 1968 by Henri Lefebvre, popularized by radical thinkers such David Harvey, and further recalled by social movements against globalization, refers to the demand for a different distribution of the city "ownership". Harvey (2008: 23) defines the right to the city as the common right "to make and remake our cities and ourselves". The making of the city implies the production of a significance that is always the result of a negotiation among different actors. An urban semiotics approach makes it possible to interpret such processes in terms of writing and co-writing of the urban text made by an overlapping of signification processes.

According to Greimas' seminal work on topological semiotics, the semiosis process is triggered by a negotiation of the different meanings and interpretations given to the city by its inhabitants (Greimas 1976: 138). The city geography is thus composed of a variety of elements (for instance roads, neighbourhoods, squares, bridges, malls, parks, etc.) and the "sum" of the manifold readings by its users. City dwellers or tourists can 
follow the instructions given by the informative structure of the city or contravene it through tactical actions (De Certeau 1990). The act of crossing the city and walking through it can be considered as an enunciation act by which the citizens instantiate their city and confront the dominant ideology of the city.

Nonetheless, such an informative gesture of rebellion gives account of the unity of the city's composition behind the plurality of elements that are intertwined within it. The above-mentioned tensions among the different city actors for ownership and authorship of the city are thematized by different textualities which compose and articulate the urban fabric: for instance, a monument can be considered as the inscription of a (new) memory intertwined with previous ones.

As a city sign, an urban-human face portrait literarily provides the city with eyes that gaze and in turn are gazed upon. In the following, a trajectory along a series of "urban-human faces" will be outlined, focusing on the figurative and plastic elements of the face composition that unveil the underlying tensions concerning the semiotic right to the city.

\section{The urban face of the leader in the Socialist city}

The overlapping between the face and the iconographies of power finds one of the first cultural manifestations in face gigantism. The Mount Rushmore National Memorial, with the colossal sculpture that features the 60 -foot $(18 \mathrm{~m})$ faces of the US Presidents George Washington, Thomas Jefferson, Theodore Roosevelt and Abraham Lincoln is one of the most remarkable examples of representation of the power (in this case over a nation) through the face. Yet face gigantism can be considered as a cultural isotopy across historical ages and cultures: from the face of the Buddha swallowed by a tree's gnarled roots, to the face of King Antiochus scattered around an empty plain in southeast Turkey around $60 \mathrm{BC}$, to the 180 -foot high monument to Decebalus, the last king of Dacia, on the banks of the Danube River. The character of colossality entails the capacity of such faces to be seen at a distance, and by doing so also to overview the natural landscape. The anthropomorphization of the landscape creates a tension between the human presence and the natural elements to which the latter is exposed with a domination aspiration.

When it comes to the city landscape, the domination is no longer projected to natural elements, but to a landscape composed (mainly) by other human figures, embodied by the notion of the urban crowd. 19th- and 20th-century literature, philosophy and art have extensively and in different ways problematized the dialectic between the individual and the crowd and their intersections in the context of urban life. Figuratively, the alienation and reification in the modern city 
have been represented by the accumulation and the repetition of indistinct faces.

According to Benjamin's vision of the modern city, expressed in his narratives in Das Passagen-Werk, the crowd is composed of an unremarkable repetition of multiple faces (Benjamin 1990: 674). Such repetition of faces is similar to the accumulation of items and goods stored in Émile Zola novel Bonheur des Dames where the "gigantesque étalage", composed of "des pièces de lainage et de draperie, mérinos, cheviottes, molletons" overwhelm the protagonist Denise who has recently arrived in Paris from the province (Zola 1883: 761). Similarly, in Benjamin's description of the 'flâneur', the latter is represented as someone abandoned in the crowd and thus as a victim of a commodity intoxication.

In opposition to an indistinct agglomeration of miniaturized faces, the face of the person standing out in the crowd expresses a potential difference, and entails a sort of primus inter pares effect. Soviet propaganda often represented the act of standing out by using the technique of photomontage. Both in the poster Stalinists! Extend the front of the Stakhanovite movement! (1936) and in Varvara Stepanova's photomontage The Results of the First Five-Year Plan (1932), the oversized face of the leader emerges from an undistinguished and anonymous crowd (Fig. 1). The charismatic leader is responsible not only for the crowd, but also for designing the new urban landscape, as depicted in the poster Glory to Great Stalin, the Architect of Communism by N. Petrov and Konstantin Ivanov (1952) on which Moscow, proclaimed by Stalin as the ideal model of the cosmos, appears as alive with pedestrians, cars and river traffic in the background.

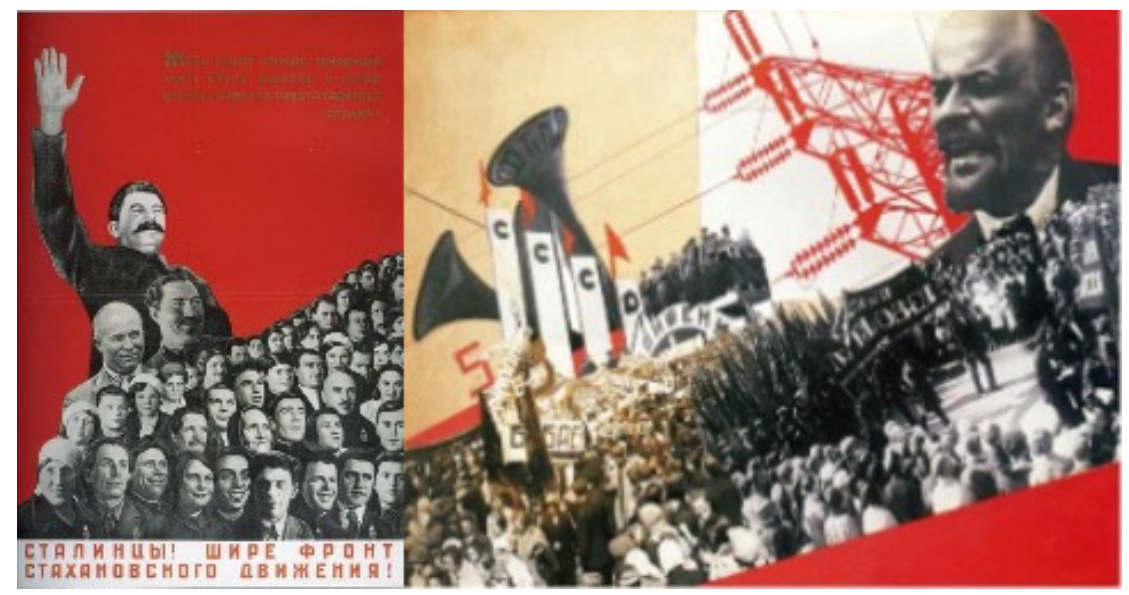

Figure 1. Stalinists! Extend the front of the Stakhanovite movement! Futerfas, 1936. (https:// digital.library.pitt.edu/) and The Results of the First Five-Year Plan. Varvara Stepanova, 1932. (AP Art History). 


\section{The urban face of the capital in the global city}

If in the 20th-century Soviet regime the oversized face of the leader being opposed to the miniaturization of the masses thematizes a relationship of domination between the former who gazes over the latter, the images of the capital and the city display a multiplication and expansion of point of views.

Already in the modern city, as described by Benjamin (1990: 537), the reflective surface of the windows "brings the open expanse" and thus deceives the eye of the flâneur. In the era of globalization, the illusion of the space expansion, accompanied by the multiplication of goods and products, has been detonated by capillary diffusion of the digital screens that reflect the augmented spaces in the urban landscape. The geographer David Harvey (1989: 66) describes the urban fabric, cultivated by the postmodern architecture movement ${ }^{6}$ as a fragmented "palimpsest" of different temporalities.

The collage effect is also encompassed by the 'media city', a notion with a long academic trajectory, that has also been defined as 'information city' (Castells 1989). In the words of McQuire (2008: 22), it refers to "a heterogeneous spatial regime, composed by a new conjunction of media and architecture". In such a new urban scenario, the augmentation of space is also caused by the overlapping between different regimes of speed: the speed of the body, the speed of vehicles, and the "absolute" light-speed of media and communication technologies (Virilio 1986).

The geographical and symbolic centre of the city, where the charismatic leader in the 20th-century totalitarian regimes emanated his absolute power over the crowd as depicted in the propaganda representations, has been delocalized and the political influence is exercised by occupying the channels of communication. The link between being omnipresent on the media, or even the ownership of media groups, and the political influence can ben epitomized by the figure of Italy's former Prime Minister Silvio Berlusconi, whose face appearing on his various channels of television became the symbol of the "media-ization" of power (Fig. 2). At the same time, Milano 2, the residential area and headquarters of the first Italian private television channel at the border of Milan, is the epitome of a decentred utopic urban space.

\footnotetext{
6 Postmodern architecture became a movement in the late 1970s, in response to the formalism of the International Style. Postmodernity is considered to be heralded by the reference and the ornament and the Disneylandization of the contemporary urban environment, epitomized by the American city of Las Vegas (Venturi, Scott Brown, Izenour 1977).
} 


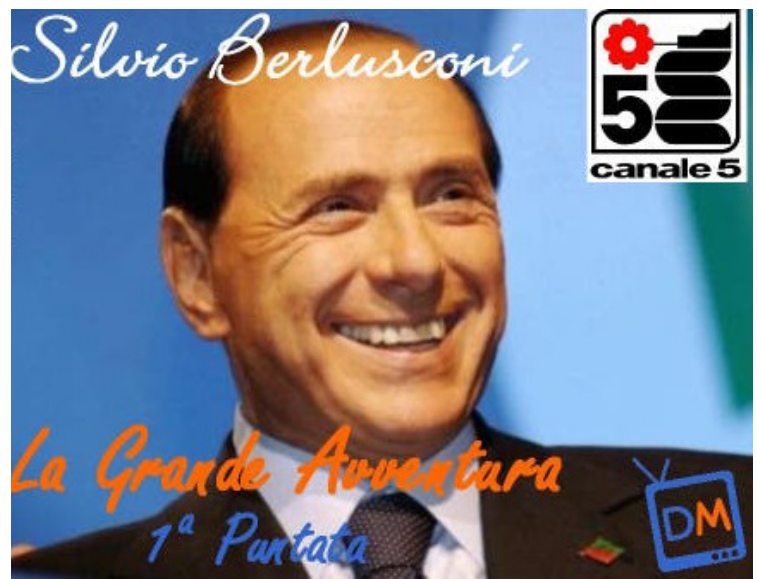

Figure 2. Silvio Berlusconi featured for a TV programme.

Even though symbolic urban spaces of consumption such as Times Square in New York City, Piccadilly Circus in London or Shibuya Scramble Crossing in Tokyo, still exhibit giant faces gazing upon the citizens (Fig. 3), the media city and its ideology have entered citizens' homes.

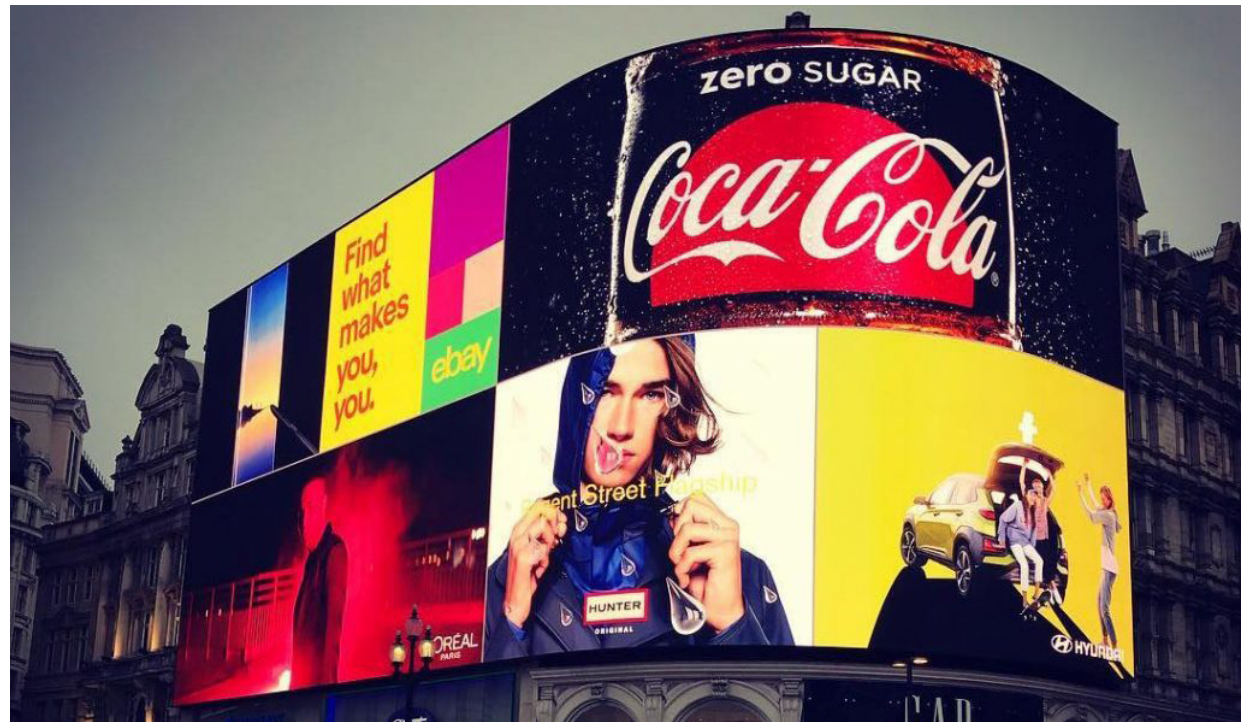

Figure 3. Piccadilly Circus billboards. 
Derrida (2002: 79) describes the "desire" to be at home created in the context of global city as follows:

We are witnessing such a radical expropriation, deterritorialization, delocalization, dissociation of the political and the local, of the national, of the nation-state and the local, that the response, or rather the reaction, becomes:

'I want to be at home, I want finally to be at home, with my own, close to my friends and family' [...] The more powerful and violent the technological expropriation, the delocalization, the more powerful, naturally, the recourse to the at-home, the return toward home.

The human-urban face, reproduced on the TV screens of each and every citizen, has been further augmented through its diffusion in the Internet. As another relational space of consumption, alternative both to public and private space, the cyberspace as an augmented substitute of the real sites increases the possibilities of the urban space and its point of views. Projects based on virtual reality such as the online virtual world Second Life, opened to public in 2003, have nurtured a parallel city created by the articulation of new forms of social collective interactions among facial avatars.

\section{The urban face of the citizens in the participatory city}

The digital transformation which has, technologically speaking, been feeding the mediascapes described above is also considered to be the precondition for the rise of the so-called 'smart city'. This concept has become a major topic in the recent discourse on city development (Crivello 2015) and has been widely discussed in and out of academia, by pointing out its dimension of "global discourse network" (Joss et al. 2019: 4). Strictly intertwined with sustainability and innovation, one of the storylines that has informed the global smart city discourse has been participation as a means to boost the democratization of the city management.

In an allegedly smart city, the citizens are provided with several platforms and tools that supposedly are meant to enable citizens' participation in different domains such as environment, economy, mobility, education and politics. ICT would thus empower the citizens to design and debate solutions about city challenges and issues and eventually to have a voice in the public debate, contributing to its governance (Simonofski et al. 2019).

The social innovation discourse has popularized the notion as co-creation of urban living and promoted practices such as hackathons or data boot camps by stressing the need to design and develop new smart city applications in 
collaboration with citizens. On the company and business side, notions such as 'co-production', 'prosumption' and 'peer-to-peer' are some manifestations of the socalled sharing economy (or in its critical version, platform capitalism ${ }^{7}$ ) which refer to the enrolling of the users on the demand side of the market through supposedly disintermediated relationships.

The concept of participatory art has been recently galvanized by city administrations at a global level as a tool for providing the community with a new sense of ownership of public space. Within this framework, the visualization of citizen's faces in artistic practices has become the figurative counterpart of the participative smart city. In opposition to the photomontages of the totalitarian leader's oversized face that stood out from an indistinct mass, and in opposition to the dispersion and fragmentation of power representations in the media city ideologies, the following projects articulate a facial participative discourse and, by so doing, a collective ownership of the city.

The French artivist JR has focused in his artistic research around faces through a participative process. In fact, in several projects of his, faces of the citizens have wallpapered different emblematic spaces, such as the Israeli West Bank Barrier, the favelas of Rio de Janeiro, the Mexican border city Ciudad Juarez or the police station in La Goulette, Tunisia, burnt down during the revolution. The art historian Claire Bishop (2006: 1) defines the artist's "interest in collectivity, collaboration, and direct engagement with specific social constituencies" as "the social turn" in contemporary art. In the case of JR, such a new form of participatory urban storytelling has the face portrayal pasted on city surfaces at its core. Entire faces can be pasted side by side, transforming a wall into a photo gallery (for instance in Face $2 \mathrm{Face}^{8}$ ), or appear as fragments, as in the case of the resistant vinyl photos of women's eyes in Women are Heroes ${ }^{9}$ (Fig. 4).

7 The concept of 'platform capitalism' was introduced by the English scholar Nick Srnicek (2017) to describe how the foundations of the economy after the crisis of 2008 were being carved up among a small number of monopolistic platforms such as Airbnb, Uber, etc.

8 Face 2 Face, Israel and the West Bank. In the project JR paired up depicting Israelis and Palestinians in locations on either side of the Separation Wall. Face 2 Face was accessed at https://www.jr-art.net/projects/israel-palestine.

9 Women are Heroes, different locations. In the project JR portrayed women in their daily lives and pasted them in relevant urban locations, such as Rio de Janeiro favelas and the Kibera slum in Nairobi, Kenya. Women are Heroes was accessed at https://www.jr-art.net/projects/riode-janeiro. 


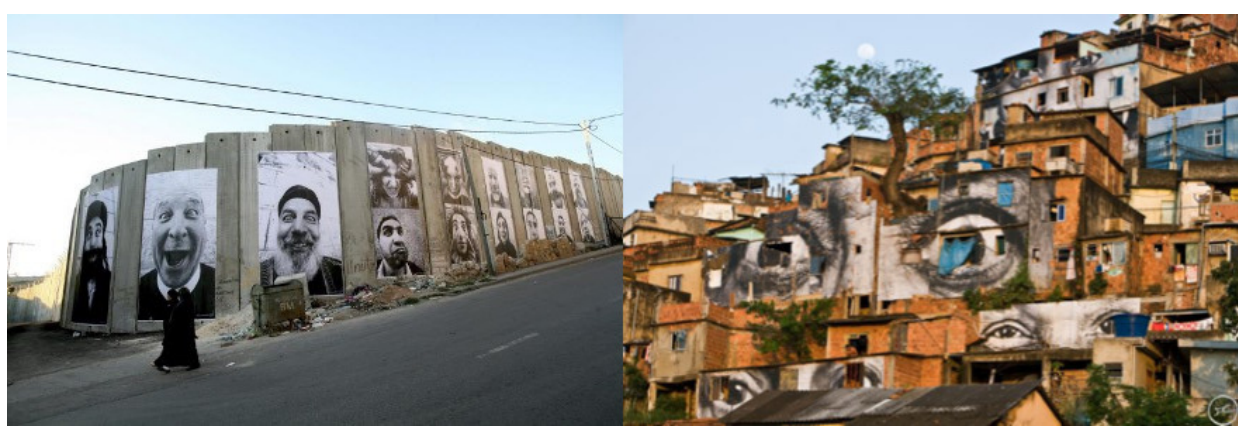

Figure 4. Face2 Face; Women are Heroes. JR (https://www.jr-art.net/projects).

In the latter, the faces have been broken down and fragmented into their details to create a proper facialization of the city. The informal and uneven surfaces of the urban slums have been equipped with a gaze that looks at the spectators by means of giving visibility to what is traditionally excluded by the city's visibility regimes. However, the sociologist Mubi Brighenti (2019: 16) argues that through experiments such as JR's "the city of faces may end up obscuring more than clarifying what the face of the city is about [...]. If it exists, the face of the city cannot be reduced to a selection of some of its dwellers' faces".

Although presuming that just the presence of citizens faces alone would enable real democratization processes might be simplistic, the figurative mechanisms make it possible to visualize the principle of the composition by creating a specific meaningful mise-en-scène. In this regard, the collage used by JR can be interpreted not just as a past technique, but, instead, as a composition method that is made up of different-sized pieces: the collage (of faces) city shows thus a mélange of different pieces, as a series of differences that have been brought together in a unique composition.

Unlike the collage, the mosaic is a composition made up of pieces of the same size. In this line, Selfiecities ${ }^{10}$ (Fig. 5) also defends the idea of the web, and consequently a city, owned by users: "Contrary to earlier incarnations of the web that were focused on content created by professionals, companies, and organizations, we are now producing, sharing, or tagging massive amounts of our own images and videos" (Hochman, Manovich 2013, s.p. $)^{11}$. According to such

10 The project explores a dataset of 3200 Instagram selfie photos shared in 5 global cities, and creates different visualizations of these photos with custom software. The website of the project at http://selfiecity.net/ was accessed in November- December 2020.

11 Acceded online 2020 at https://firstmonday.org/article/view/4711/3698 in NovemberDecember. 
rhetoric, Second Life avatars have been replaced by "real" citizens faces. The aim of the project led by Lev Manovich and his team at CUNY is to question what visual social media, and in particular Instagram, tells us about the relationship between the city and individuals. As opposed to Manovich's previous projects ${ }^{12}$, this inquiry put the faces of city dwellers at the centre, by specifically investigating the style of self-portraits (selfies).

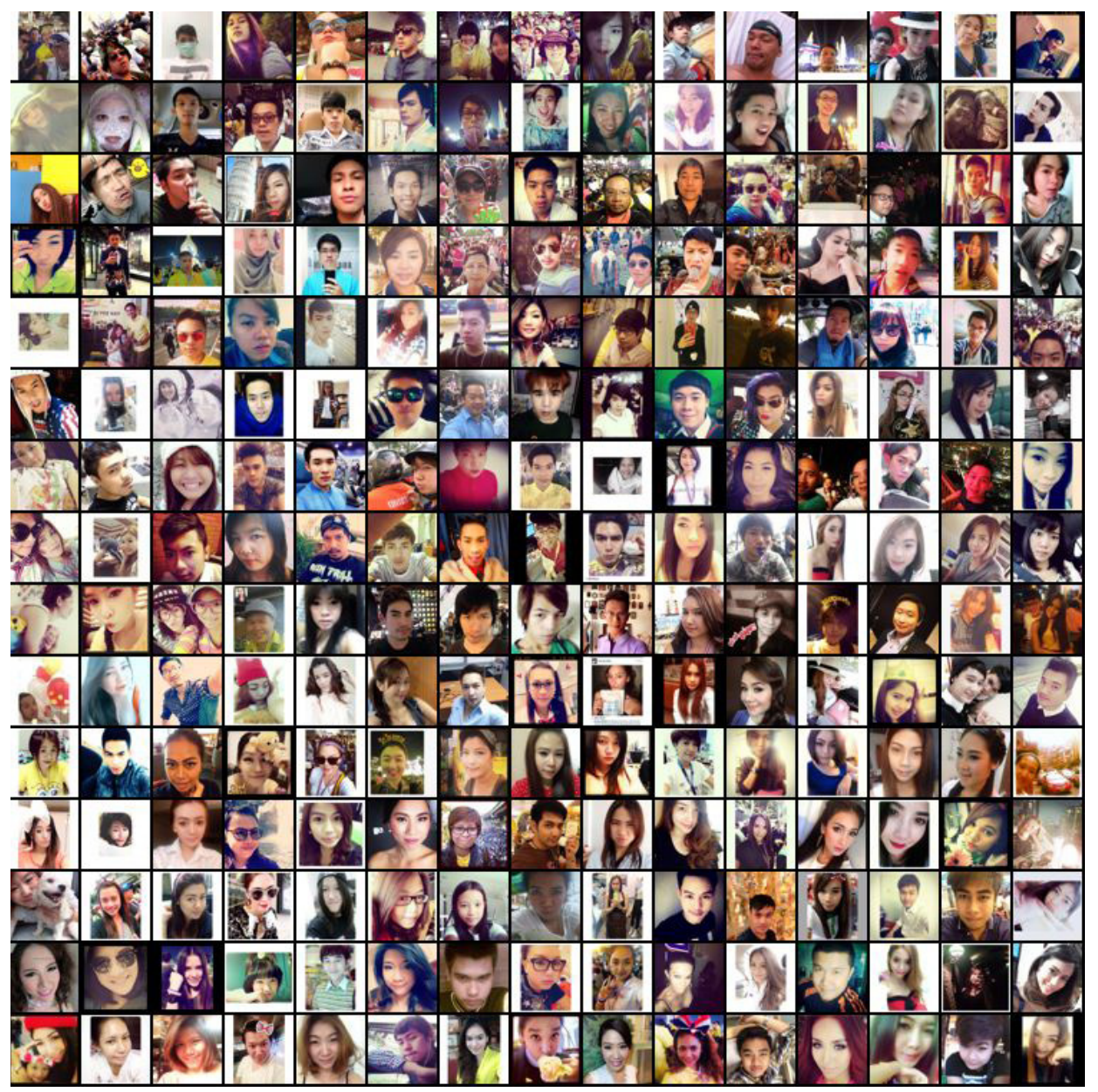

Figure 5. Selfiecities, Bangkok. Manovich (http://selfiecity.net/).

12 Lev Manovich's all projects can be browsed at http://manovich.net/index.php/projects/ tag:Project. 
The project collected 656,000 images downloaded on Instagram, in five cities (New York, Sao Paulo, Berlin, Bangkok, and Moscow) over a specific lapse of time (4-12 December 2013). The rudimentary automatic face analysis has been supplemented by human judgment, through the inspection by Mechanical Turk workers, in order to estimate the ages and genders of the people in the photos. The facial expressions of the selfies in a city have also been studied for instance examining which city smiles the most, with Bangkok smiling the most and Moscow the least. The project's conclusions focus, among other things, on how, despite Instagram being a universal language, its usage changes according to the geography.

From a merely composition point of view Selfiecities appears as mosaics of faces, which can be explored following visual patterns and rhythms across the sets. The miniaturized faces are contained in a grid, side by side, in a series. The pieces of the mosaic have the same, regular size and together they create a unified series which does not present either discontinuity or rupture. Unlike the digital maps that track communities' clusters and mark distances and proximity among them (as well as visualizing inclusion and exclusion processes), the Selfiescities, apparently, advocates for denying hierarchies and categories, by displaying the gesture of posting a composite self-portrait.

\section{Conclusion}

We have been observing the urban-human face(s) as configuration(s) that allow us to unveil the tensions for the semiotic "ownership" and "authorship" of the city. In the semiotics of culture, the city has been depicted as polyphonic and as a polylogue in an isomorphic relation with the semiosphere as a whole. Following this principle, the series of urban-human faces analysed diachronically in the piece should be embraced in a synchronic way as well. Therefore, the assignation of a face to a model of a city is always an incomplete operation as the city, from the point of view of semiotics, is the result (always open) of the writing and rewriting operations by different "authors" (for instance the "delegates" of a certain urban ideology) who, together, orchestrate conflicting urban narratives.

Arguably, cities cannot have just a face unless we consider this as an unstable semiotics mechanism. Therefore, the commensurability of the city and the face can be based on the fact that both semiotic configurations represent an excess with a cartographic reproduction (the city) and a portrait (the face), respectively. A city can be represented by a face to the extent to which it is also multifaceted as a polylogue. The aim to represent the struggle for the ownership of the city by addressing the question to whom the city belongs is thus condemned to a fail, yet this study has tried to give an account of such a failure. 
To finalize the trajectory with a new start, a famous quote from Jorge Luis Borges $E l$ Hacedor could be employed - an epilogue that refers to a man who wanted to draw the world and populate the is world with all sorts of geographic elements such as provinces, kingdoms, mountains, bays, ships, islands, fishes, rooms, instruments, stars, horses, and individuals. Just before dying, the man discovers that "the patient labyrinth of lines traces the lineaments of his own face" (Borges 1960: 126). At present, cities and faces are both involved in processes of resemantization of their respective geographies. In such crucial times, following Borges' image, we must not avoid the fact that, isomorphically speaking, the act of drawing a space entails drawing a face.

Acknowledgements: This project has received funding from the European Research Council (ERC) under the European Union's Horizon 2020 research and innovation programme (Grant agreement No 819649 - FACETS).

\section{References}

Atkinson, Rowland; Blandy, Sarah (eds.) 2006. Gated Communities: International Perspectives. London, New York: Routledge.

Atkinson, Rowland; Flint, John 2004. Fortress UK? Gated communities, the spatial revolt of the elites and time-space trajectories of segregation. Housing Studies 19(6): 875-892. https://doi.org/10.1080/0267303042000293982

Benjamin, Walter 1990. The Arcades Project. Cambridge: Harvard University Press.

Bishop, Claire 2006. The social turn: Collaboration and its discontents. Artforum International 44(9): 24-24.

Black, Daniel 2011. What is a face? Body \& Society 17(4): 1-25. https://doi.org/10.1177/ $1357034 \mathrm{X} 11410450$

Borges, Jorge Luis 1960. El Hacedor. Buenos Aires: Emecé Editores.

Castells, Manuel 1983. The City and the Grassroots: A Cross-Cultural Theory of Urban Social Movements. London: Arnold.

Castells, Manuel 1989. The Informational City: Information Technology, Economic Restructuring, and the Urban-Regional Process. Oxford, Cambridge: Blackwell.

Crivello, Silvia 2015. Urban policy mobilities: The case of Turin as a Smart City. European Planning Studies 23(5): 909-92. https://doi.org/10.1080/09654313.2014.891568

Davis, Mike 1990. City of Quartz: Excavating the Future in Los Angeles. London: Vintage.

De Certeau, Michel 1984. L'invention du quotidien. Paris: Gallimard.

Deleuze, Gilles; Guattari, Félix 1980. Mille Plateaux. Paris: Minuit.

Derrida, Jacques, 2002. Echographies of Television: Filmed Interviews. Cambridge: Polity Press.

Farinelli, Franco 2009. La crisi della ragione cartografica. Torino: Einaudi.

Ferdman, Bertie 2012. Urban dramaturgy: The global art project of JR. PAJ. A Journal of Performance and Art 34(3): 12-26. https://doi.org/10.1162/PAJJ_a_00107 
Greimas, Algirdas 1976. Sémiotique et sciences sociales. Paris: Éditions du Seuil.

Hardt, Micheal; Negri, Antonio 2009. Commonwealth. Cambridge: Harvard University Press. https://doi.org/10.2307/j.ctvjsf48h

Harvey, David 1973. Social Justice and the City. London: Arnold.

Harvey, David 2008. The right to the city. New Left Review 53: 23-40.

Hochman, Nadav; Manovich, Lev 2013. Zooming into an Instagram City: Reading the local through social media. First Monday 18(7), s.p. https://doi.org/10.5210/fm.v18i7.4711

Joss, Simon; Sengers, Frans; Schraven, Daan; Caprotti, Federico; Dayot, Youri 2019. The Smart City as global discourse: Storylines and critical junctures across 27 cities. Journal of Urban Technology 26(1): 3-34. https://doi.org/10.1080/10630732.2018.1558387

Ivanov, Vyacheslav 1986. K semioticheskomu izucheniyu kul'turnoi istorii bol'shogo goroda'. [On the semiotic research of the cultural history of the big city].Trudy po znakovym sistemam [Sign Systems Studies] 19: 7-23.

Lefebvre, Henry 1991. The Production of Space. Oxford, Cambridge: Blackwell.

Lotman, Juri M. 1984. On the semiosphere. Sign Systems Studies 33(1): 205-226. https:// doi.org/10.12697/SSS.2005.33.1.09

Lotman, Yuri M. 1990. Universe of the Mind: A Semiotic Theory of Culture. London: I. B. Tauris.

Lotman, Juri; Uspenskij, Boris 1977[1973]. Myth - name - culture. In: Lucid, Daniel (ed.), Soviet Semiotics: An Anthology. Baltimore: Johns Hopkins University Press, 233-252.

Massey, Doreen 1996. The age of extremes: Concentrated affluence and poverty in the twenty-first century. Demography 33(4): 395-412. https://doi.org/10.2307/2061773

McGrath, Brian 2006. Face city. Space and Culture 9(3): 235-244. https://doi.org/10.1177/ 1206331206289363

Mubi Brighenti, Andrea 2019. Face and the city. Body \& Society 17(4): 1-25. https://doi. org/10.1177/1357034X19865941

Schneider, Jane; Susser, Ida (eds.) 2003. Wounded Cities: Destruction and Reconstruction in a Globalized World. Oxford: Berg.

Simone, AbdouMaliq 2010. City Life from Jakarta to Dakar. New York: Routledge. https:// doi.org/10.4324/9780203892497

Simonofski, Anthony; Vallé, Troy; Serral, Estafania; Wautelet, Yves 2019. Investigating context factors in citizen participation strategies: A comparative analysis of Swedish and Belgian smart cities. International Journal of Information Management 56: 1-10. https://doi.org/10.1016/j.ijinfomgt.2019.09.007

Skop, Emily 2006. Urban space: The shape of inequality. Urban Geography 27(5): 393-396. https://doi.org/10.2747/0272-3638.27.5.393

Srnicek, Nick 2017. Platform Capitalism. Cambridge Polity Press.

Uspenskij, Boris A; Ivanov, Vjacheslav. V.; Toporov Vladimir N.; Pjatigorskij Alexander. M.; Lotman, Juri M. 2003. Theses on the semiotic study of cultures (as applied to Slavic texts). In: Eng, Jan van der; Grygar, Mojmír (eds.), Structure of Texts and Semiotics of Culture. The Hague, Paris: Mouton, 1-28. https://doi.org/10.1515/9783110802962-002 Venturi, Robert; Scott Brown, Denise; Izenour, Steven 1977. Learning from Las Vegas. Cambridge, MA: The MIT Press.

Virilio, Paul 1986. Speed and Politics. New York: Semiotext(e). 
Young, Iris Marion 1990. Justice and the Politics of Difference. Princeton: Princeton University Press.

Zola, Emile 1883. Bonheur des Dames. Paris: Hatier.

\section{Городские и человеческие лица и семиотическое право на город: от механизма пропаганды СССР до города соучастия}

Ситуация, в которой использование и значение городских пространств было серьезно подорвано глобальной пандемией, породила множество дискуссий и размышлений о том, каким образом устроены города - как общественные, так и частные пространства. Статья рассматривает, как репрезентация «городского человеческого лица» стала основой различных моделей урбанизма в разные эпохи и культуры. Исходя из семиотики культуры, согласно которой город представляет собой модель мира, в статье предпринята попытка интерпретировать, как портреты лиц моделируют город с помощью различных механизмов градостроительства. В центре внимания оказывается то, что мы называем «городским человеческим лицом» - начиная от советских пропагандистских плакатов до цифрового проекта \#selfiecity. Это понятие относится к ряду образов, объединяющих город и лицо. Можно утверждать, что и город, и лицо, произведенные в конкретный историкокультурный момент, с их образными и пластическими элементами, разворачивают борьбу за право на город и на его авторство.

Тем не менее, соизмеримость города и лица может быть основана только на том факте, что обе семиотические конфигурации представляют собой избыток с помощью картографического воспроизведения (город) и портрета (лицо) соответственно. Город может представлять лицо в той степени, в которой он многогранен как полилог. Исходя из такой неустойчивой соизмеримости, статья в конечном итоге попытается свести воедино семиотику лица и семиотику города.

\section{Linlik-inimlikud näod ning semiootiline õigus linnale: NSVL propagandamasinast osaluslinnani}

Nüüd, mil globaalne pandeemia on linnaruumi kasutamisele ja tähendusele dramaatilise väljakute esitanud, on käimas mitmed debatid ja arutelud teemal, kuidas linnad - nii avali$\mathrm{ku}$ ja avalikkuse ees olevat privaatset ruumi osas kui ka privaatse ruumina - on kujundatud. Artklis täheldatakse, et "linlik-inimliku näo" representatsioonid on erinevatel aegadel ja kultuurides teeninud erinevaid linlikkuse mudeleid.

Kasutades kultuurisemiootikast tuletatud raamistikku, mille kohaselt linn esindab maailma mudelit, püüatakse artiklis tõlgendada seda, kuidas näoportreed on linna modelleerinud, erinevate linlike näolisusmehhanismide kaudu. Fookuses on kogum nähtusi, mida me nimetame "linlik-inimlikeks nägudeks" ja mis ulatuvad Nõukogude propagandaplakatitest digitaalse \#selfiecity projektini. Väljend osutab reale representatsioonidele, mis toovad kokku linna ja näo. Võib väita, et nii linn kui ka nägu, mis on produtseeritud konkreetsel ajaloolisel ja kultuurilisel hetkel, oma figuratiivsete ja plastiliste elementidega, sisaldab võitlust linna omamise ja autorsuse üle. 
Linna ja näo ühismõõtmelisus võib tugineda lihtsalt tõigale, et mõlemad semiootilised konfiguratsioonid esindavad liiasust, vastavalt kartograafilise reprodutseerimise (linn) ja portree (nägu) abil. Nägu võib esindada linna sel määral, mil see on polüloogina paljutahuline. Sellise ebastabiilse ühismõõtmelisuse põhjal püüab artikkel viimaks kokku tuua näo- ja linnasemiootika. 